\title{
Continuing Professional Development opportunities in Information and Communication Technology for academic librarians at the Durban University of Technology
}

\author{
Anushie Moonasar ${ }^{1}$ and Peter G. Underwood ${ }^{2}$ \\ anushiem@dut.ac.za ORCID: orcid.org/0000-0001-7885-3597 \\ pgunderwood@wol.co.za ORCID: orcid.org/0000-0002-9618-5032
}

\begin{abstract}
Received: 23 May 2018
Accepted: 14 August 2018

Continuing Professional Development (CPD) is a vital tool for maintaining the skills and expertise of staff, especially with regard to the use of Information and Communication Technology (ICT). There is little information available about the involvement of librarians in South Africa with CPD: this study focused on academic librarians at the Durban University of Technology (DUT) Library, seeking their attitudes towards CPD and its provision. It employed a qualitative approach in its research design. Questionnaires were utilised to collect information from twenty-five academic librarians. Follow-up interviews were conducted with five respondents. The overall study indicated that, although the respondents were aware of the importance of CPD and the impact of ICT on library resources and services, not all of them kept abreast of CPD activities within their field. The respondents believed that the institutions and the professional body, the Library and Information Association of South Africa (LIASA), should work together to encourage and promote CPD activities. By encouraging CPD activities within the Library and Information Science (LIS) sector, the quality of librarianship and service delivery within the LIS would improve. Half of the respondents agreed about the importance of CPD becoming compulsory within the LIS profession and 55\% of respondents considered that LIASA had a potentially important role to play in promoting CPD. However, in separate interviews, several respondents expressed doubt about the capacity of LIASA to fulfil this role.
\end{abstract}

Keywords: Professional development, continuous learning, academic librarians, professional development activities, information communication and technology

\section{Introduction and background}

Continuing Professional Development (CPD) is about ensuring that individuals have the opportunity to keep up-to-date with trends and continuously learn and improve their subject and professional knowledge. Information and Communication Technology (ICT) has had an impact on the way librarians operate and function, offering them more opportunities to serve their user communities. Adanu (2007: 294) suggested that continuous learning in the workplace is important and that managers and employers should be supportive of this trend, as it is an essential element in the development of an employee. The IFLA/UNESCO Public Library Manifesto provides the principle:

The librarian is an active intermediary between users and resources. Professional and continuing education of the librarian is indispensable to ensure adequate services (International Federation of Library Associations and Allied Institutions [IFLA] \& United Nations Educational, Scientific and Cultural Organization [UNESCO] 1994).

Recognition of the significance of CPD in professional development has steadily improved and the skills set employed by librarians is seen to be significant to the survival of the profession. Corcoran and McGuinness (2014: 182) emphasised the importance of regular and planned upgrading of the skills set. Ajeemsha and Madhusudhan (2012: 20) believe that librarians need to be more alert to ICT changes and their effect on the Library and Information Science (LIS) sector.

It is also important that institutions acknowledge the significance of continuous updating of the professional knowledge and skills of librarians. Although the Library and Information Association of South Africa (LIASA) has

1. Anushie Moonasar is Coordinator: Cataloguing and Classification Librarian at Durban University of Technology, South Africa

2. Peter G. Underwood is a dissertation supervisor for the University of Pretoria, South Africa 
acknowledged the importance of CPD and has made an attempt to encourage librarians to plan for continuously updating their skills, it has not been enforced as a compulsory requirement, although a commitment to CPD is enshrined within its Code of Ethics and Conduct (LIASA 2013). This is somewhat in contrast to several other countries, including the United Kingdom and the United States of America, where development of a CPD portfolio is considered essential for career advancement in the LIS sector (Owens \& Watson 2015: xvi, American Library Association 2002: 9). Change is likely, however, because LIASA sought recognition by the South African Qualifications Authority (SAQA) as a Professional Body. Its registration, according to the National Qualifications Framework Act 67 of 2008, requires a CPD system to be developed, promoted and applied (LIASA 2018a). LIASA's application was concluded successfully in December 2014, the announcement being made on 9 February 2015 (LIASA 2015). A Professional Body Advisory Committee has been constituted (LIASA 2018b) and a schedule of CPD activities and requirements promulgated (LIASA 2018c).

\section{Problem statement}

The information available on the perception of the need for CPD by the LIS sector in South Africa is limited. The LIS sector in South Africa promotes CPD courses but problems are encountered: Walker (2009) presented a detailed analysis in relation to academic research libraries; despite the passage of time since Walker's study, the lack of a satisfactory framework for CPD has remained. The reasons for non-take-up of CPD opportunities vary from lack of finances to the reluctance of management to release staff to attend the courses. It is imperative that the country's professional bodies take a stance on CPD and ensure that the LIS sector is on board with encouraging CPD within their institutions. A recent study highlights the problem more generally across the professions in South Africa: ". . . there is considerable variety in CPD practices and a lack of a common language in describing these. CPD appears to be low-stakes in a majority of professional bodies" (Financial Planning Institute of Southern Africa 2015: 3).

With the ongoing changes and the impact of ICT on the library sector, the role of CPD in developing and maintaining the skills set of practitioners is potentially important. It is imperative that librarians have the relevant knowledge and are up-to-date with the technological changes that impact on their profession. Academic librarians are expected to be proficient in information searching and must ensure that their evaluation skills are up-to-date in order to assist researchers. The questions to be explored in this research were:

- To what extent do academic librarians in South Africa appreciate the need for CPD and how do they perceive the opportunities that CPD could offer?

- To what extent do academic institutions provide for CPD and encourage participation?

\section{Literature review}

CPD is commonly defined as "an ongoing process aimed at monitoring and upgrading skills and competence of individual workers in the profession" (Doney 1998: 487) 3 $^{3}$ The aim is to remain abreast within one's profession, with the understanding that CPD is a continuous undertaking; a commitment to lifelong learning. Once formal education is completed, it does not mean that learning will end.

Academic librarians are at the centre of the academic institution ${ }^{4}$ and are generally expected to anticipate the needs of researchers and students in respect of techniques for information searching and evaluation. According to Larsen (2006: 1), librarians are expected to be knowledgeable and deliver an excellent service to their users: this objective is often compromised by inadequate finances and lack of training. It is vital that librarians endeavour to upgrade their knowledge and skills constantly throughout their career (Freeman 1994: 28) and that they supplement their core skills with the new technology that is available. An academic librarian's skills are vital in managing collection development and delivering quality services to their users (Maesaroh and Genoni 2010: 625). It is essential that librarians are aware of the changes and the new initiatives that arise within the LIS sector (Ritchie et al. 2010: 277). Choi and Rasmussen (2009: 457) point out that the impact of technological advancements on libraries affects library structure because the changes may engender reorganising the responsibilities of librarians within the departments. This implies that existing librarians need to be exposed to continuous learning initiatives in order to embrace new job functions and changes. According to Lamptey and Corletey (2011: 2), excellent service delivery within the LIS sector depends upon librarians being knowledgeable, of a high professional calibre and continuously engaged in CPD activities.

3. The definition was developed by a group of librarians attending a seminar in the United Kingdom; the passage of time has otherwise obscured their identity.

4. The metaphor of the library as the "heart of the university' is first attributed to Charles Eliot, who served as President of Harvard, from 1869 to 1909. See Harvard University, Annual report of the President of Harvard University to the Overseers on the state of the university for the academic year 1873-1874. President's Report for 1873-74. [Online]. https://iiif.lib.harvard.edu/manifests/view/drs:427074985\$41i (20 March 2018). 
The evidence for this change and the need created can be detected in the way jobs are advertised. The requirements for librarians are constantly changing and now require the librarians to have specific skills suitable for academic libraries and knowledge of current technological aspects (Choi and Rasmussen 2009: 458). Corrall (2010: 567) emphasised that the changes that transpire within the academic institutions provide opportunities and challenges for academic librarians. According to Ahmad and Yaseen (2009: 6), CPD should be an important aspect of any professional vocation. Librarians are required to be adaptable in their ability to embrace change and upgrade their skills in accordance with new trends in ICT.

The aim of CPD is to allow individuals to broaden and deepen their knowledge within their profession, on a continuous basis. CPD is a route that individuals aim to follow in order to enhance their existing knowledge and skills by participating in various ongoing courses and activities (Megginson, Whitaker and Chartered Institute of Personnel and Development 2007: 3). Ongoing learning allows individual to keep abreast of changing trends in their field. It is imperative that individuals seize opportunities to develop their skills at the appropriate stages of their career paths (Brine 2005: 2), underlining the importance of self-motivation being accompanied by an opportunity to engage in CPD. CPD is a catalyst for various career developments for individuals and the added skills boost the individual's confidence and competency levels. Lamptey and Corletey (2011: 2) described CPD as the way in which individuals of a professional group can develop, maintain and widen their knowledge and skills. This description underlines the importance of self-motivation being accompanied by opportunities to engage in CPD. If either - or both - is absent, then CPD is unlikely to be successful. Weingand's (1999: 201) contention highlights the problem:

The shelf life of a degree is approximately three years and declining. Maintaining competence and learning new skills must be at the top of every professional's "to do" list. It is an ethical responsibility, to be sure, but also one that is pragmatic and critical for career success. [...] Continuing professional education is no longer an option, it is a requirement of professional practice.

The impact of ICT on the LIS sector was a catalyst for librarians to embrace continuing education and has forced librarians to keep up with changing trends in order to be able to deliver services competently to their patrons (Cooke 2012: 2). Librarians are expected to sustain their competitive edge and work well in a fast-changing environment. CPD courses are potentially able to assist librarians closing the gap between formal education and needs of the library by maintaining their authority over this changing environment (Majid 2004: 59).

In South Africa, although CPD courses and training are common, it is not a compulsory aspect of professional development in all sectors; however, with the recent recognition by SAQA of LIASA as a professional body, those members who have been afforded professional status will have to demonstrate and maintain a portfolio of attendance at CPD courses and events. According to Havener and Stolt (1994: 35), it is important that individual institutions support and encourage CPD activities within their institutions. Institutions can support librarians by allowing them time away from their daily duties to engage in CPD activities and provide financial assistance to attend the courses. According to Majid (2004: 61), the professional associations within individual countries are the best sources for hosting and implementing CPD initiatives. These bodies should work together with LIS schools in order to promote and encourage CPD activities with librarians. Majid (2004: 69) believes that CPD should not only be considered as an ad hoc activity but that it should be part of the core activities within the LIS professional education.

LIASA is an established professional body that has membership from all sectors and will accept application for affiliate membership from any other organisation that is involved with information services within South Africa. According to Lamptey and Corletey (2011: 6), it is important that professional bodies engage with their membership on a regular basis in order to determine the types of continuous learning initiatives that the members within the various LIS sectors require in order to upgrade their knowledge and skills. LIASA has taken the initiative of promoting various CPD courses and training as well as highlighting the CPD initiatives of other institutions. It is therefore highly desirable for all librarians to become members of their professional associations in order to become aware of the range of CPD activities on offer.

\section{Challenges presented by CPD programmes and initiatives}

Librarians encounter many challenges with CPD among which funding attendance and financing subsistence and travel can be counted as major limiting factors. These costs make it difficult for employers to allow all their staff to attend courses due to budget constraints and lack of funding (Brine 2005: 124).

According to Adanu (2007: 301), for CPD to succeed within an institution, it needs actively to promote continuous educational activities. It is also important that librarians who attend the CPD courses are genuinely interested in upskilling themselves as it would be futile to send individuals who had no intention of furthering their skills. The other challenge of attending CPD courses is the lack of time. Employers are reluctant to release their employees from their everyday jobs 
and are aware of the potentially limiting effect on services of having staff absent. Another challenge is the cut-off age. Most CPD courses are aimed at the younger generation and more experienced librarians may be side-lined (Corcoran and McGuinness 2014: 184). The lack of support from a manager can be another stumbling block for librarians who are keen on attending CPD activities (Cossham and Fields 2007: 578).

There is a dilemma faced by those involved in CPD provision and its management in an organisation. On the one hand is the need for enhancement of professional skills to provide enhanced service to the user communities; on the other is the problem of budget and time allocation. Encompassing this dilemma is the fundamental problem of how CPD opportunities are perceived by professionals.

\section{Research methodology}

This study focused on the issues that the academic librarians at the Durban University of Technology (DUT) Library experienced with regards to CPD, to identify how CPD will help academic librarians progress within their profession and to determine suitable actions for the efficient application of CPD initiatives within the South African LIS sector. The data collection methods employed for this study were self-administered online questionnaires and interviews. The research design employed for this study was a case study method as it allowed the researchers the flexibility of focusing on a small group of subjects in order to draw data for the study (Kothari 2004: 116). The research approach was based on an explorative qualitative research study model and this allowed the researchers to collect and analyse data around the concept of CPD opportunities in ICT for academic librarians at the DUT Library. According to Babbie (2016: 90), exploratory research helps to clarify issues and allows for a better understanding of the study undertaken by allowing follow-up interviews and clarification of issues.

Durban University of Technology is a multi-campus university with six site libraries based in Durban and Pietermaritzburg. The study population focused on twenty-five out of the forty-six professionally qualified librarians employed at the DUT Library. The researchers chose to use purposive sampling for this study because it allowed them to engage the flexibility and use of their own knowledge in selecting the sample target (Babbie 2016: 187). The librarians that were chosen were judged to have better insight about CPD-related initiatives and had previously expressed an interest in the development of the programme at DUT. Another advantage of this sampling method is the cost and timesaving related to it (Kothari 2004: 59).

An online self-administered questionnaire was utilised for this study as it was easy to send to librarians spread across the six site libraries and allowed respondents to complete the questionnaire at their own pace. An interview was used as a follow-up to the questionnaire and allowed for clarification of responses received. An interview gives the researcher an added advantage in observing the body language of participants when responding to specific questions. An online tool, QuestionPro, was employed to administer the questionnaire. Follow-up interviews were conducted once the data from the questionnaire had been collated.

\section{Findings}

A total of twenty, out of twenty-five, completed surveys was received. The findings revealed that all the participants shared the opinion that CPD was important and improved the professional competence of individuals. The participants were in agreement that involvement in CPD activities improved their understanding of ICT and the effect it has on libraries. The participants at the DUT Library believed that, at their library, CPD activities were supported and encouraged.

\subsection{Participant demographics}

The survey requested participants to identify their current positions at DUT, the number of years they had occupied these positions and their highest qualification, as shown in Table 1. Information about age and gender was not gathered. All participants in the study were in possession of a professional library qualification and, with the exception of one, had been employed at the DUT Library for three years or more. One respondent was fairly new and had just completed one year of service at the Library. The participants in this study were from various sections of the Library namely, acquisitions, cataloguing, periodicals, circulation and subject librarians.

\subsection{CPD perceptions and opinions}

The participants were clear in their understanding of what CPD was and the importance of it within their discipline. They understood the importance of CPD in their own development as well as the impact it could have on the service delivery of a library. Respondents recognised that CPD improved their professional competence. 
Table 1 Participant demographics

\begin{tabular}{|c|c|c|}
\hline Current position at DUT & No. of years in current position & Highest qualification \\
\hline Circulation librarian/coordinator & 8 years & Masters in LIS \\
\hline Assistant Librarian: Circulation & 5 years & Bachelor of Information Science \\
\hline Assistant Librarian: Circulation & 3 years & Bachelor of Technology: LIS \\
\hline Site Coordinator and Information Services & 7 years & B.Bibl. (Hons) \\
\hline Library Assistant & 4 years & Bachelor of Technology: LIS \\
\hline Library Assistant & 1 year & Bachelor of Technology: LIS \\
\hline Subject Librarian & 7 years & Postgrad diploma: LIS \\
\hline Subject Librarian & 6 years & Masters \\
\hline Subject librarian & 5 years & Masters \\
\hline Subject Librarian & 11 years & Bachelor of Technology: LIS \\
\hline Subject Librarian & 25 years & Masters of Technology: LIS \\
\hline Subject Librarian & 5 years & Masters \\
\hline Subject Librarian & 8 years & Bachelor of Technology: LIS \\
\hline Subject Librarian & 1 year & Bachelor of Technology: LIS \\
\hline PG/Subject Librarian & 7 years & Masters in Library and Information Sciences \\
\hline Librarian & 5 years & Masters \\
\hline Librarian & 5 years & Honours degree \\
\hline Assistant Librarian Acquisitions - Periodicals & 3 years & B.Inf. \\
\hline Acquisitions and E-Resources Librarian & 6 years & Masters in Library Science \\
\hline Cataloguing and Classification Librarian & 8 years & Bachelor of Technology: LIS \\
\hline
\end{tabular}

These outcomes (presented in Figure 1) were similarly aligned to the work of Larsen (2006: 1), Maesaroh and Genoni (2010: 621) and Megginson, Whitaker and the Chartered Institute of Personnel and Development (2007: 3). The librarians accepted the importance of the impact of ICT on the profession and believed that CPD should be a personal aim of all librarians: they perceived that professional development required personal commitment to broaden existing knowledge and skills. They also noted that CPD could have a positive impact on their careers. This sentiment aligned with the findings of Ahmad and Yaseen (2009: 6), who believed that participation in CPD was a significant aspect of career advancement for librarians. Librarians were cognisant of the fact that CPD activities should not interfere with the functioning of the library and that it was necessary that CPD activities coincide with vacation periods. However, several respondents indicated that they were not pleased to be left with an extra workload while colleagues were participating in CPD activities. It was clear all twenty of the DUT librarians that participated in the study believed that CPD should accommodate all librarians irrespective of their job functions and qualifications.

\subsection{Participation in CPD activities}

All twenty participants indicated that involvement in CPD activities improved their understanding of ICT and had a positive effect on the library. Surprisingly, only $50 \%$ of the respondents in this study felt that CPD should be enforced in order for librarians to keep up-to-date within their profession. Ensuring that CPD is made compulsory allows the librarians to be proactive in keeping themselves informed through participation in CPD initiatives within their profession. Although the librarians understood the importance of continuing their education within their field, it was interesting to note that CPD was not something that should be forced upon individuals: rather, effective CPD depends upon willing participation. The findings revealed that DUT Library supported and encouraged its librarians to participate in CPD initiatives, and participants were satisfied that they were encouraged to participate in CPD activities that were in line with their current jobs. This sentiment was aligned to that of Kont and Jantson (2015: 368), who expressed the belief that librarians needed to be encouraged to enhance their educational and professional qualifications. The participants understood that it was important that they took the initiative to keep updated about new trends by subscribing to alerts, blogs, newsletters and various other tools within their professional interests. Ai-Ling (2009) and Horvat (2004) concurred in their findings that individuals needed to be well-informed of developments by attending conferences, participating in workshops, reading, and by subscribing to various online tools. Although a large proportion (95\%) of participants was satisfied with approaches to CPD activity within DUT Library, some $5 \%$ expressed dissatisfaction with regards to allocation of staff to 
CPD activities (see Figure 2). The ideal is for CPD to foster growth and development of all librarians, regardless of their level within the library.

\section{Figure 1Opinions and perceptions of CPD}

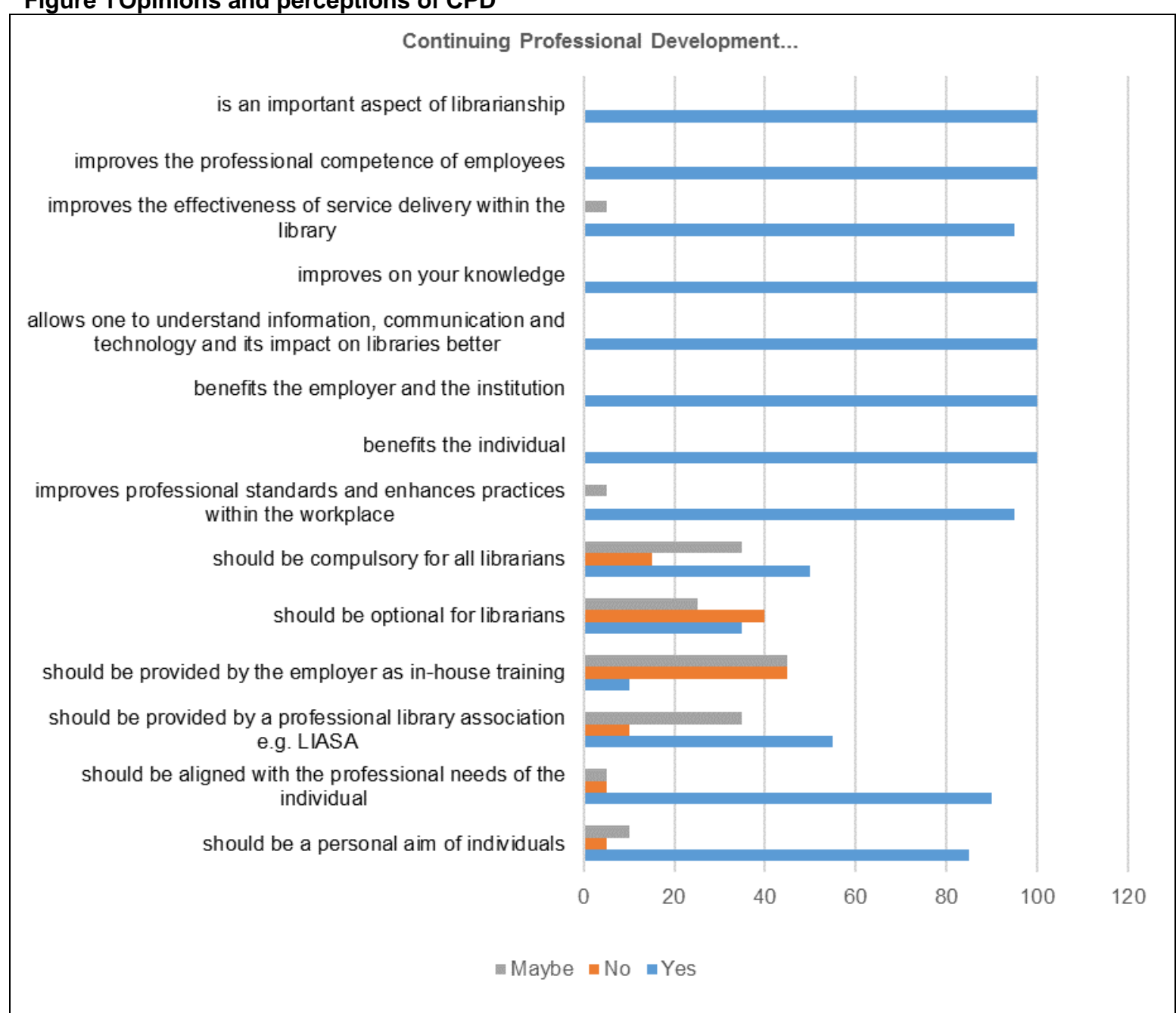

Figure 2 Participation in CPD activities

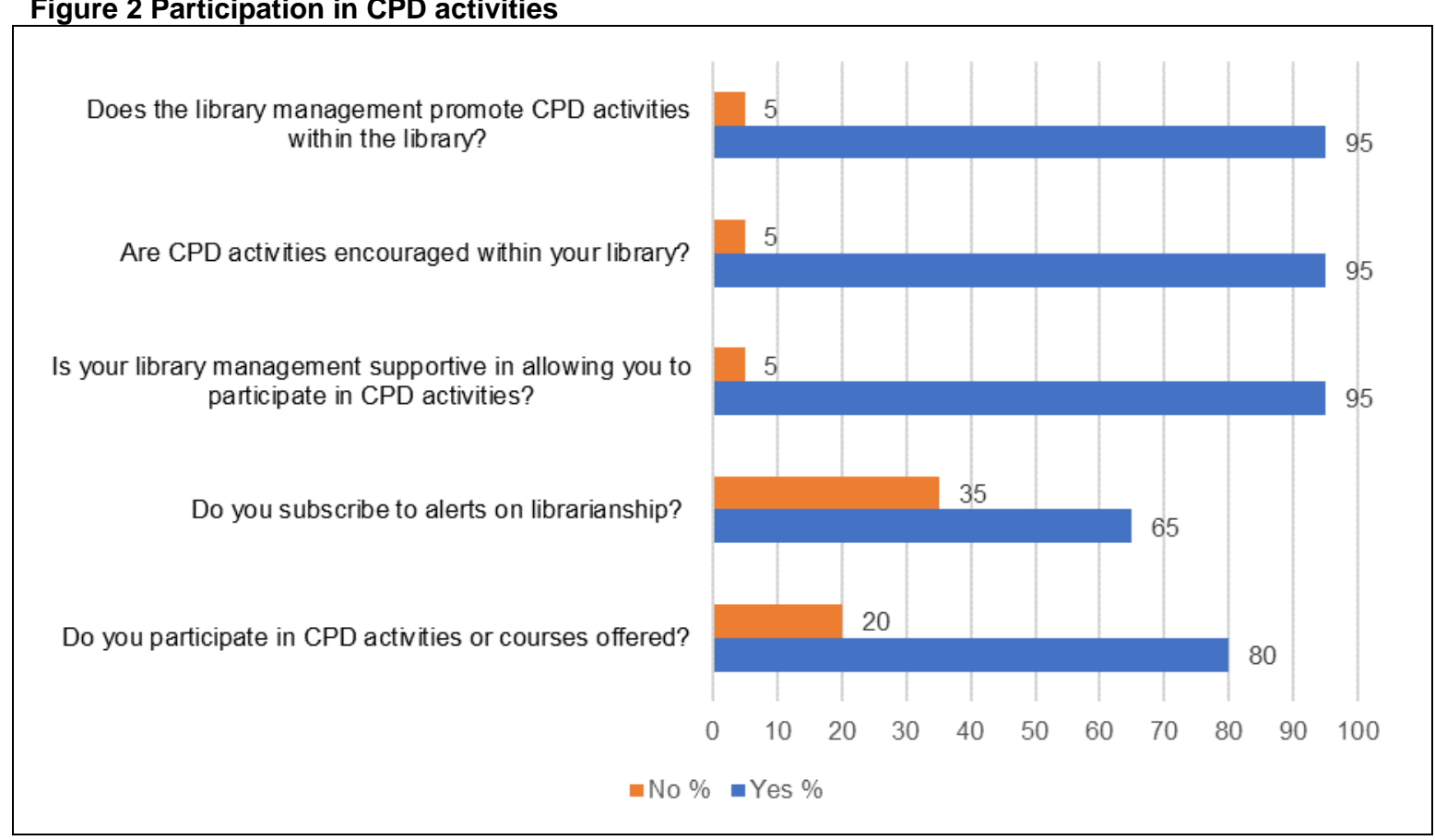




\subsection{Impact of ICT}

Participants indicated that, when encouraged to participate in CPD activities and to embrace the impact of ICT and other changes, they are able to rise to the resulting challenges (Kont and Jantson 2015: 368). They understood the need to remain proactive and to keep abreast of changing technologies and welcomed CPD activities that highlighted the effects that ICT had on their libraries. They believed that they needed to be a step ahead of their users especially when it came to the retrieval and access of information.

\subsection{National professional association}

The participants believed that LIASA needed to be more assertive in its promotion of CPD activities. Information should be filtered down to the entire LIS sector; institutions should in turn market the activities within their libraries. According to Varlejs (2016: 35), the onus is on the professional association to ensure that the dissemination of information on CPD initiatives is accurate and regularly communicated to all LIS sectors. The participants believed that the LIASA membership and conference fees were high and beyond the personal budget of many librarians. All participants suggested that LIASA should start providing accredited CPD short courses online for librarians to attend. These would enable librarians to enhance their skills and knowledge with regards to evolving technological changes. The interactive courses would encourage librarians to partake actively in online activities at their own pace and in the safety of their offices.

During the interviews, which engaged with five of the questionnaire respondents, the participants pointed out that, due to the cost of membership being so high, they were not LIASA members and thus did not receive LIASAcommunicated information. They were divided over their expressed satisfaction levels with LIASA. There was recognition that LIASA had offered training and workshops in the past, but also an opinion that LIASA could do more for paraprofessionals in the LIS sectors. It was clear from the range of response that there was room for improvement regarding LIASA and its CPD-related activities.

In South Africa, LIASA and many academic institutions run separate CPD activities for librarians. According to Freeman (1994: 26), all CPD initiatives should be coordinated by the national structure within the country so that courses and activities are streamlined. The notion of various institutions sharing knowledge and transferring skills should be encouraged by the national association. It is essential that national structures take the initiative to coordinate CPD initiatives within their respective countries and thereby encourage regional and provincial partnership between the LIS sectors.

\section{Recommendations}

It is vital that librarians are well-informed and updated on the current trends in their profession. The study done at the DUT Library confirms that it is imperative that librarians regularly engage in continuous learning activities to ensure that their professional knowledge is well-rounded and that they are comfortable with technology and change. According to Lamptey and Corletey (2011: 2), service delivery depends on this. It is recommended that librarians are kept in touch with changing developments through alerts, online webinars and various other informative blogs. Librarians are able to learn from their peers, colleagues and fellow librarians by simply keeping in contact about developments and their application. Encouraging various forms of mentoring and coaching between librarians allows for the transfer of knowledge and skills and thus allows for further growth. According to Sayers (2007: 485), by coaching and mentoring the future generation of librarians, the profession would be kept current and the profession would be less likely to decline in significance.

Having access to essential professional development opportunities can encourage librarians to value their profession and shape the future of learners and users in an ever-changing technological environment. Joining interest groups with colleagues from other institutions can allow for the exchange of ideas and encourage continuous learning. Fisher and Matarazzo (as cited in Kont and Jantson 2015: 368) stressed the significance of keeping up with ICT changes and the impact of international norms on libraries. A well-informed librarian is better prepared to respond to user needs. However, there are implications for how this process is managed: budget restrictions at DUT Library restricted ability to participate in CPD activities. Similarly, finances were highlighted as a challenge in Brine's (2005) study.

LIS educators should be encouraged to work closely with the professional domain to identify practical examples to share with students, and the curriculum should be aligned to incorporate and support the changing trends and the impact of ICT on libraries. Furthermore, LIS educators should remain involved in promoting CPD activities and develop continuous learning activities for postgraduate students and other librarians (Varlejs 2016: 38). The professional associations should work closely with the professional domain to plan CPD activities in ways that allow greater flexibility for employees to attend courses and activities. This type of cooperation can help with the financial challenges that institutions face. Employees who are competent and skilled in their respective fields of interest can also help in leading 
and coordinating CPD activities. A pool of experts from institutions should be formed and utilised for training of other librarians.

\section{Conclusion}

This study highlights the importance of employers encouraging and motivating their staff to engage in CPD activities. The promotion of CPD participation creates further benefits by encouraging more interaction and the forging of relationships between colleagues nationally and internationally.

It is apparent that maintaining professional knowledge and competence requires regular revision and renewal, especially in a profession that is constantly evolving. The results of this study indicate that, while the significance of CPD is well acknowledged, the uncertainty surrounding the mandatory aspect of it for librarians still needs to be probed. It is important that librarians and information workers from the LIS sector familiarise themselves with the available CPD guidelines so that they are not limited in the selection of activities in which they can engage. Librarians should be encouraged to develop personal learning plans that can aid them in monitoring and improving their current and future career plans within the profession.

\section{References}

Adanu, T.S. 2007. Continuing professional development (CPD) in state-owned university libraries in Ghana. Library Management, 28(6/7): 292-305.

Ahmad, P. and Yaseen, M. 2009. The role of the library and information science professionals as managers: a comparative analysis. Electronic Journal of Academic and Special Librarianship, 10(3): 1-10.

Ai-Ling, Y. 2009. Continuous professional development for librarians. Jurnal Persatuan Pustakawan Malaysia, 3: 33-44.

Ajeemsha, S and Madhusudhan, M. 2012. Competencies for LIS professionals in the working environment: analysis and dimensions. International Journal of Library and Information Studies, 4(3): 18-25.

American Library Association (ALA). 2002. Library and Information Studies and human resource utilization: a statement of policy adopted by the Council of the American Library Association, January 23, 2002. Chicago, IL: ALA. [Online]. http://www.ala.org/educationcareers/sites/ala.org.educationcareers/files/content/careers/paths/policy/lepu.pdf (8 August 2018).

Babbie, E.R. 2016. The practice of social research. 14 $4^{\text {th }}$ ed. Boston, Mass.: Cengage Learning.

Brine, A. 2005. Continuing professional development: a guide for information professionals. Oxford: Chandos.

Choi, Y. and Rasmussen, E. 2009. What qualifications and skills are important for digital librarian positions in academic libraries? A job advertisement analysis. The Journal of Academic Librarianship, 35(5): 457-467.

Cooke, N.A. 2012. Professional development 2.0 for librarians: developing an online personal learning network (PLN). Library Hi Tech News, 29(3): 1-13.

Corcoran, M. and McGuinness, C. 2014. Keeping ahead of the curve: academic librarians and continuing professional development in Ireland. Library Management, 35(3): 175-198.

Corrall, S. 2010. Educating the academic librarian as a blended professional: a review and case study. Library Management, 31(8/9): 567-593.

Cossham, A. and Fields, A. 2007. Balancing individuals' expectations and organisational requirements for continuing professional development. Library Review, 56(7): 573-584.

Doney, E. 1998. Developing opinions: the attitudes of ILS staff to continuing professional development. Library Management, 19(8): 486-491.

Financial Planning Institute of Southern Africa. 2015. Continuing Professional Development Practices (CPD) in recognised professional bodies: an initial survey by SAQA-FPI. Johannesburg: SAQA/FPI. [Online]. https://www.fpi.co.za/documents/CPD_research_paper_Sept2015.pdf (20 March 2018).

Freeman, M. 1994. A sense of direction: librarianship and CPD. Librarian Career Development. 2(3): $26-28$.

Havener, W.M. and Stolt, W.A. 1994. The professional development activities of academic librarians: does institutional support make a difference? College \& Research Libraries, 55(1): 25-36.

Horvat, A. 2004. Continuing education of librarians in Croatia: problems and prospects. New Library World, 105(9/10): 370-375.

International Federation of Library Associations and Allied Institutions (IFLA) \& United Nations Educational, Scientific and Cultural Organization (UNESCO). 1994. IFLA/UNESCO Public library manifesto. The Hague: IFLA. [Online]. https://www.ifla.org/publications/iflaunesco-public-library-manifesto-1994 (8 August 2018).

Kont, K.R. \& Jantson, S. 2015. Librarians work-related learning and self-development: trends in Estonian University Libraries. American Journal of Educational Research, 3(3): 366-376.

Kothari, C.R. 2004. Research methodology: methods \& techniques. Rev. $2^{\text {nd }}$ ed. New Delhi: New Age International.

Lamptey, R.B. and Corletey, A. 2011. Building strong libraries and library associations through continuing professional development: the case of Ghana Library Association. Proceedings of the World Library and Information Congress and 77th IFLA General Conference and Assembly. 13-18 August 2011. Puerto Rico, San Juan. [Online]. http://www.ifla.org/past-wlic/2011/125-lamptey-en.pdf (27 December 2016).

Larsen, G. 2006. Preparing for new and changing roles in research libraries - the need for continuing professional development. Liber Quarterly, 16(3-4): 1-10. 
Library and Information Association of South Africa (LIASA). 2013. Code of ethics and conduct. [Online]. http://www.liasa.org.za/code-of-ethics-conduct/ (22 March 2018).

Library and Information Association of South Africa (LIASA). 2015. Recognition of LIASA as a registered, professional body. [Online]. http://www.liasa.org.za/recognition-of-liasa-as-a-registered-professional-body/ (8 August 2018).

Library and Information Association of South Africa (LIASA). 2018a. Overview of Continuing Professional Development (CPD). [Online]. http://www.liasa.org.za/continuing-professional-development-cpd/ (8 August 2018).

Library and Information Association of South Africa (LIASA). 2018b. LIASA Professional Body Advisory Committee. [Online]. http://www.liasa.org.za/liasa-professional-national-board/ (8 August 2018).

Library and Information Association of South Africa (LIASA). 2018c. CPD activities and requirements. [Online]. http://www.liasa.org.za/cpd-activities-and-requirements/ (8 August 2018).

Maesaroh, I. and Genoni, P. 2010. An investigation of the continuing professional development practices of Indonesian academic libraries. Library Management, 31(8/9): 621-634.

Majid, S. 2004. Continuing professional development (CPD) activities organized by library and information study programs in Southeast Asia. Journal of Education for Library and Information Science, 45(1): 58-70.

Megginson, D., Whitaker, V. and Chartered Institute of Personnel and Development. 2007. Continuing Professional Development. 2nd ed. London: Chartered Institute of Personnel and Development.

Owens, K. and Watson, M. 2015. Building your portfolio: the CILIP guide. $3^{\text {rd }}$ ed. London: Facet.

Ritchie, A., Hallam, G., Hamill, C., Lewis, S., Foti, M., O'Connor, P. and Clark, C. 2010. Designing a specialist postgraduate qualification and continuing professional development structure for the health librarian workforce of the future. Australian Academic \& Research Libraries, 41(4): 276-299.

Sayers, R. 2007. The right staff from $X$ to $Y$ : generational change and professional development in future academic libraries. Library Management, 28(8/9): 474-487.

Varlejs, J. 2016. Continuing professional development: principles and best practices. [Online]. https://www.ifla.org/files/assets/cpdwl/guidelines/ifla-guidelines-for-continuing-professional-development.pdf (24 August 2016).

Walker, C. M. 2009. Pathways to new academic library practices: South African exploration towards $21^{\text {st }}$ century academic research support. In Strategies for regenerating the library and information profession. J. Varlejs and G. Walton, Eds. Munich: De Gruyter Saur. 402-415. (IFLA Publications 139). [Online]. https://www.degruyter.com/downloadpdf/books/9783598441776/9783598441776.7.402/9783598441776.7.402.pdf (20 March 2018).

Weingand, D.E. 1999. Describing the elephant: what is continuing professional education? IFLA Journal, 26(3): 198-202. 